Araştırma Makalesi/Research Article

\title{
Bitlis İli Anadolu Mandası İşletmelerinin Genel Yapısal Özellikleri Üzerine Bir Araştırma
}

\author{
Serkan Çiftçi ${ }^{1}$ \\ ${ }^{1}$ Diyarbakır Tarım ve Orman İl Müdürlüğü Gıda ve Yem Şubesi \\ ${ }^{2}$ Siirt Üniversitesi Ziraat Fakültesi Zootekni Bölümü \\ 'Sorumlu yazar: ayilmaz@siirt.edu.tr
}

\author{
Ayhan Yilmaz ${ }^{2 *}$
}

Kabul Tarihi: 16.04.2019

\section{$\ddot{\mathbf{O} z}$}

$\mathrm{Bu}$ çalışma Bitlis ili Güroymak ve Mutki ilçelerinde manda yetiştiriciliği yapan işletmelerin genel yapısal özelliklerini belirlemek için yapılmıştır. Araştırma grubunu Bitlis ili Güroymak ve Mutki ilçelerindeki 136 manda yetiştiricisi oluşturmuştur. Anket toplam 85 soru maddesinden oluşturulmuştur. Elde edilen veriler SAS paket programında analiz edilmiştir. Araştırmada, Bitlis ilinde manda yetiştiriciliğinin temelde orta yaş grubu veya daha büyük yaş grubundaki yetiştiriciler tarafından gerçekleştirildiği, yetiştiricilerin barınak ve işçi giderleri için bir maliyetlerinin söz konusu olmadığı, sağımın elle sağım yöntemiyle ahırda yapıldığı, malaklarını hiç sütten kesmedikleri, başta eşeysel olgunluk yaşı olmak üzere pek çok döl verim özelliğinin arzulanan düzeyde olmadığı, ortalama günlük süt verimi için bildirilen değerin düşük olduğu saptanmıştır. Bununla birlikte Mutki ilçesinde Güroymak ilçesine göre başta boğa bulundurma olmak üzere eşeysel olgunluk yaşı, damızlıkta kullanma süresi ve laktasyon süresi bakımından görülen farklılıklar önemli bulunmuştur $(\mathrm{P}<0,05)$. Sonuç olarak, Bitlis ili mandacılığına ilişkin elde edilen bulguların ülke hayvancılığımızın geleneksel yapısından ayrı düşünülmeyeceği, önemli bir gen kaynağı olarak Anadolu mandasının korunması ve alternatif bir yetiştirme kolu olarak değerlendirilmesinin hayvansal üretimin artırılması açısından bir fayda sağlayacağı saptanmıştır.

Anahtar Kelimeler: Anadolu mandası, Bitlis, manda, süt verimi

\section{A Research on the General Structural Characteristics of Anatolian Buffalo Farms in Bitlis Province}

\section{Abstract}

The aim of this study was to determine the production practices and the general structural characteristics of Anatolian buffalo reared in Güroymak and Mutki districts of Bitlis province. In this research, 136 breeders were questioned in the production of buffaloes in the districts of Güroymak and Mutki in Bitlis province. The questionnaire was composed of 85 questions. The data obtained were analyzed in Statistical Analyzes System (SAS). It was observed that buffalo production in Bitlis region was carried out by middle-aged or older breeders and no cost for shelter and labor expenses in these farmers, and that buffaloes milked by hand within shelters and the their calves were not weaned for long time. Further the production traits of Anatolian buffalo raised in these regions were not at the desired level, especially the reproduction characteristics and average lactation yield. However, the differences between the districts in terms of bull keeping, puberty, breeding period and lactation length were found to be significant in favor or Mutki county $(\mathrm{P}<0.05)$. As a result, the findings of the province of Bitlis should not be considered separately the traditional structure of the our animal production, the protection of Anatolian buffalo as an important genetic source and an important alternative branch of animal production for future will be beneficial in terms of increasing animal production.

Keywords: Anatolian buffalo, Bitlis, buffalo raising, milk yield

\section{Giriş}

Et, süt ve çeki hayvanı olarak kullanılan manda, Güney Amerika, Kuzey Afrika, çoğu Akdeniz ülkeleri, bazı Orta Avrupa ülkeleri, Balkan ülkeleri, Güneydoğu Asya ve Avustralya gibi bölgelerde yetiştirilmektedir (Anonim, 2007). Manda, çoğunlukla Asya kıtasında (\%96,4) varlık göstermekte ve temelde geleneksel bir yetiştiricilik yapısına sahiptir. Dünya manda varlı̆̆ının ülkesel dağılımına bakıldığında Hindistan (\%55), Pakistan (\%17) ve Çin (\%13) gibi ülkeler ilk sıralarda yer alırken, bu ülkeleri Nepal (\%3), Mısır (\%3), Vietnam (\%2) ve Filipinler (\%2) takip etmektedir. En fazla manda bulunduran ilk üç ülke Hindistan, Pakistan ve Çin, dünya manda varlığının \%85'ni elinde 
bulundurmaktadır. Bu ülkelerde manda yetiştiriciliği genellikle ekstansif yöntemlerle yapılmakta olup, düşük kaliteli kaba yemler ile bataklık ve sazlık alanlardan faydalanılmaktadır. Avrupa kıtasında ise İtalya entansif manda yetiştiriciliğiyle öne çıkan bir ülke olarak görülmektedir. İtalya'da entansif manda yetiştiriciliğinin yanı sıra organik manda yetiştiriciliği de önemli bir sektör olarak dikkat çekmektedir (Sarı̈̈zkan, 2011).

Ülkemiz mandaları ise Akdeniz mandasından köken alan Nehir mandaları grubunun Anadolu mandası 1rkıdır (Soysal, 2013). Anadolu mandası, Tarım ve Orman Bakanlığı Tarımsal Araştırmalar ve Politikalar Genel Müdürlüğü tarafından 2004 yılı itibariyle ırk tescili yapılmış ve tanımlanmıştır (Anonim, 2004). Türkiye'de 1970-2008 yılları arasında manda popülasyonundaki bir milyon başın üzerindeki keskin düşüş, bu genetik kaynağımızın gen kaynaklarının korunması bağlamında önemli bir genotip olarak belirmesine yol açmışıı (Sarı̈zkan, 2011). Bununla birlikte 2008-2014 yılları arasında manda sayısındaki artış \%44 düzeyinde olup, manda yetiştiriciliği açısından önemli bir gelişme olarak değerlendirilmektedir. Manda yetiştiriciliğinin kendine özgün özelliklerinin ortaya konulması, Anadolu mandasındaki azalışta da açıkça gözlemlendiği gibi, yıllardır ihmal edilen bu 1rkımızın başta kültürel boyutuyla olmak üzere manda ürünlerinden faydalanılması, bu ürünlerin tanıtılması, yaygınlaştırılması ve bu yetiştirme kolunun sürdürülebilirliğinin sağlanması ülkemiz hayvancılı̆̆g için önemli olacaktır.

$\mathrm{Bu}$ çalışmada Bitlis ili Güroymak ve Mutki ilçelerinde mandacıllk faaliyetleri yürüten hayvancılık işletmelerinin genel yapısal özelliklerini ve yetiştirme alışkanlıklarını ortaya konulması amaçlanmıştır.

\section{Materyal ve Metot \\ Materyal}

Durum tespitine yönelik olan bu araştırmada, Bitlis ili Güroymak ve Mutki ilçelerinde manda yetiştiriciliği yapan 136 manda yetiştiricisi ile anket yapılmıştır. Araştırma Güroymak ilçesinin Değirmenköy, Güzelli, Budaklı ve Özkavak köyleri ile Gölbaşı ve Günkırı beldelerinde, Mutki ilçesinde ise Çitliyol köyünde yürütülmüştür. Anket, toplam 85 sorudan oluşmuştur.

\section{Yöntem}

Mevcut çalışmada kullanılan anket soruları daha önce yapılan benzer amaçlı bir çalışmada (Yılmaz, 2013) kullanılan sorulardan yararlanılarak geliştirilmiştir. Soru maddelerinin ve seçeneklerinin oluşturulmasında her soru grubu için uzman görüşlerine başvurulmuş ve buna ilişkin eksiklikler giderilmiştir.

Araştırmanın gerçekleştirildiği Bitlis ili ve ilçelerine ilişkin işletme sayısı ve manda varlığı dikkate alınarak basit tesadüfî örnekleme yöntemiyle örnek işletme sayısı hesaplanmıştır (Güneş ve Arıkan, 1989). Buna göre gerekli örneklem sayıs1 \%90 önem seviyesinde 119 bulunmakla birlikte, çalışmada toplam 136 örnekleme yapılmış, hazırlanan bu anket formları araştırmacılar tarafından yetiştiricilere verilerek uygun seçenekleri işaretlemeleri istenmiştir. Anketler yüz yüze görüşme yöntemiyle gerçekleştirilmiş ve 10-30 Mayıs 2017 tarihleri arasında yapılmıştır.

Anket soruları manda yetiştiriciliğine ilişkin olarak 4 ana başlık altında değerlendirilmiş ve gruplandırılmıştır

1. İşletme ile ilgili bilgiler (1-13 arasındaki soru maddeleri)

2. Barınak ile ilgili bilgiler (14-19 arasındaki soru maddeleri)

3. Hayvan varlı̆̆ 1 ve yetiştirme ile ilgili bilgiler (20-41 soru maddeleri)

4. Sağım ile ilgili bilgiler (42-48 arasındaki soru maddeleri)

\section{Verilerin Analizi}

Elde edilen verilerin analizi SAS 9.4 yazılımında gerçekleştirilmiştir (SAS, 2015). Ankette yer alan soru maddeleri ilçe, köy, cinsiyet, öğrenim durumu ve yaş faktörleri esas alınarak frekans ve yüzde değerleri olarak elde edilmiştir. İlçe ve köyler için belirlenen soru maddelerine ait Ki-Kare $\left(\mathrm{X}^{2}\right)$ yöntemi ile ilişkilerin önemli olup olmadığı incelenmiştir. 


\section{Bulgular ve Tartışma \\ İşletme ile ilgili bilgiler}

Durum tespitine yönelik yapılan bu araştırmada ankete katılan yetiştiricilerin yaş, eğitim durumu, cinsiyet ve ilçe durumlarına ilişsin frekanslar Çizelge 1'de verilmektedir. Ankete katılan yetiştiricilerin yaş grupları hayvancılığımızın genel yetiştirici özellikleriyle uyumlu bulunmaktadır. Başka bir ifadeyle manda yetiştiriciliği temelde orta yaş grubu veya daha büyük yaş grubundaki yetiştiriciler tarafından gerçekleştirilmektedir (Han ve Bakır, 2010; Yılmaz,2013). Trakya bölgesindeki büyükbaş hayvancılık işletmelerinin ekonomik özelliklerinin araştırıldığı bir çalışmada (Gültekin, 2014) kırsal kesimden kentlere doğru göçün hızla arttığını ve köylerde 50 yaşından küçük insan kalmadığı bildirilmektedir. Yine, Çizelge 1'de Bitlis ilinde manda yetiştiriciliğinin çoğunlukla okuryazar değil ve ilkokul mezunu yetiştiriciler tarafından gerçekleştirildiği anlaşılmaktadır. Bu durum hayvansal üretimde sürdürülebilirlik ve karlılık açısından önemli bir problem olarak görülmektedir (Han ve Bakır, 2010; Yılmaz,2013; Gültekin, 2014). Araştırmada cinsiyet durumuna ilişkin olarak elde edilen bulgular bu yetiştiricilik kolunun erkekler tarafından yürütüldüğünü göstermekle birlikte, kadının üretimdeki büyük rolünün genellikle kayıt dışı kaldığı tahmin edilmektedir (Gültekin, 2014). Araştırmada yetiştiricilerin \%97,06's1 aile işgücünden yararlanırken, \%2,94'ü aile ve iş̧̧i işgücünden yararlanmaktadırlar. Yetiştiricilerin sadece mandacılıkla uğraşanların oranı \%82,35 iken; ticaret, kamu çalışanı ve diğer sektörlerde (inşaat, bitkisel üretim vb.) çalışanların oranı sırasıyla \%4,41, \%8,09 ve $\% 5,15$ olarak saptanmıştır. İşletmede çalışanların durumu ile ilgi elde edilen bulgular, ülkemiz hayvancılığının genel yapısıyla uyumlu olduğu görülmektedir (Han ve Bakır, 2010; Gültekin, 2014).

Çizelge 1. Yetiştiricilerin demografik özelliklerine ilişkin frekanslar (\%)

\begin{tabular}{lccccc}
\hline Yaş & Frekans & $\%$ & Yaş & Frekans & $\%$ \\
\hline $20-30$ & 19 & 13,97 & Okuryazar değil & 17 & 12,5 \\
$31-40$ & 43 & 31,62 & İlkokul & 76 & 55,9 \\
$41-50$ & 30 & 22,06 & Ortaokul & 22 & 16,2 \\
$51>$ & 44 & 32,35 & Lise + Üniversite & 21 & 15,4 \\
Toplam & 136 & 100,00 & Toplam & 136 & 100,00 \\
\hline Cinsiyet & Frekans & $\%$ & İlçe & Frekans & $\%$ \\
\hline Erkek & 134 & 98,53 & Güroymak & 107 & 78,68 \\
Kadın & 2 & 1,47 & Mutki & 29 & 21,32 \\
Toplam & 136 & 100,0 & Toplam & 136 & 100,00 \\
\hline
\end{tabular}

\section{Barınak ile İlgili Bilgiler}

Ankete katılan yetiştiricilerin sahip oldukları hayvan barınağına ilişkin yanıtlar değerlendirildiğinde kira, ortak ve şahsa ait olanların değerleri sırasıyla $\% 5,15, \% 4,41$ ve $\% 90,44$ 'dür. Buna karşılık barınak mülkiyeti şirket adına olan yetiştiriciler bulunmamıştır. Dolayısıyla Bitlis ilinde manda yetiştiriciliği için bir barınak planlanması, yapı elemanlarının bulundurulması ve işçiden yararlanılması için bir maliyetin söz konusu olmadığı anlaşılmaktadır. Yetiştiricilerin büyük çoğunluğu barınağın şahsa ait olduğunu bildirmiştir. Özdemir ve Özdemir (2016) Bingöl yöresindeki çalışmasında "işletmenizde en çok harcama yaptığınız uygulama" sorusuna yetiştiriciler işçi, damızlık alımı, yem alımı ve barınak giderleri için herhangi bir harcama yapmadıklarını bildirmektedirler. Mevcut araştırmada barınak tipi açık ve kapalı olanların değerleri ise sırasıyla \%2,94 ve \%97,06'dır. Budağ ve Keçeci (2013) Van ilinde besi ahırlarında kapalı, yarı açık ve açık ahır tiplerine ilişkin oranları sırasıyla $\% 87, \% 8,8$ ve $\% 4,2$ olarak bildirmişlerdir. Bölgenin sert iklim koşulları göz önünde bulundurulduğunda kapalı barınak tipi doğru bir seçenek olarak görülmekle birlikte, barınak içi koşullar son derece sağlısız bir ortamın oluşmasına yol açmaktadır. Aynı şekilde Tugay ve Bakır (2006) Giresun'da 373 işletmede yaptıkları araştırmada barınakların \%35,7'sini müstakil, \%62,2'sini ev altı, \%2,1'ini ise ev altı-müstakil olarak bildirmişlerdir. Bu araştırmada ise özellikle Mutki ilçesinde vadilerdeki köylerde yer altı barınakların kullanıldığı gözlenmiştir.

Katılımcıların barınakta ek tesis durumuna ilişkin olarak yem deposu ve gölgelikleri olanların oranları sırasıyla \%10,29 ve \%3,68'dir. Yetiştiricilerin hepsi săğm ünitesine sahip olmadıklarını ifade etmişlerdir. Ayrıca, yetiştiricilerin büyük çoğunluğunun barınağın dışında herhangi bir ek tesise sahip 
olmadıkları saptanmıştır. Bu durum ülkemizin bazı bölgelerinde önemli bir problem olarak görülmektedir. Bununla birlikte sığır yetiştiriciliği bağlamında batı bölgelerinde önemli gelişmeler sağlandığı düşünülmektedir. Örneğin Denizli yöresinde yapılan bir çalışmada, sığır barınaklarının planlanmasında ek tesislere yer verildiği açık bir şekilde belirlenmiştir. Söz konusu araştırmada Denizli yöresi süt sığırcılığ 1 işletmelerinin \%90'dan fazlası hem kaba yem deposuna hem de sağım ünitesine sahip olduğu bildirilmektedir(Kayar, 2011).Bitlis yöresinde barınakları konuta bitişik ve konuttan bağımsız olanların değerleri ise sırasıyla \%76,47 ve \%25,53'tür. Bununla birlikte araştırmada köyün dlşılnda ve başka yetiştirici ile ortak barınak durumuna yönelik olarak herhangi bir işaretleme yapılmamıştır. Han ve Bakır (2010) Diyarbakır yöresinde yaptıkları bir çalışmada, barınakların büyük çoğunluğunun müstakil yapıda olduğunu tespit etmişlerdir. Giresun ilinde ise ev-altı barınak oranının bu çalışmada elde edilen orandan daha yüksek olduğu bildirilmiştir (Tugay ve Bakır, 2006). Mevcut araştırmada ahırların çoğunlukla konuta bitişik yapıldığı açık bir şekilde ortaya çıkmakta ve bu durum yetiştiricilerin yaşam standartlarını ve sağlık koşullarını açık bir şekilde tehdit etmektedir (Çayır ve ark., 2012). Bununla birlikte gerek Güroymak gerekse de Mutki ilçesinde bazı yetiştiricilerin konuttan bağımsız barınaklar yaptıkları gözlenmiştir. Araştırmada barınak boyutları olarak verilen genişlik, uzunluk ve yükseklik değerlerine ilişkin ortalamalar sırasıyla $7,75 \pm 0,22,13,74 \pm 0,43$ ve $2,30 \pm 0,03$ m'dir. Barınak boyutları bakımından köyler arasındaki farklılıklar istatistik olarak önemli bulunmuştur. Barınak yüksekliği bakımından Özkavak köyü diğer köylerden daha düşük barınak yüksekliğine sahiptir $(\mathrm{P}<0,05)$. Araştırmanın yapıldığı bölgede yetiştiricilerin tamamı kapalı ahır tipine sahip oldukları için bu ahır tipine uygun barınak içi koşulların oluşturulması önemli bir konu olarak görünmektedir. Özellikle barınak yüksekliğine ilişkin elde edilen değerin düşük olduğu belirtilebilir. Gönce ve Gökçe (2017) kapalı tip ahırlarda barınak yüksekliğinin en az $3 \mathrm{~m}$ olması gerektiğini bildirmişlerdir.

Yetiştiricilerin gübre değerlendirme durumuyla ilgili olarak gübreleri bitkisel üretim, yakacak, hem yakacak hem de bitkisel üretim olarak değerlendirenlerin oranları sirasıly \%5,00, \%4,00ve $\% 91,00$ 'dir. Bununla birlikte gübre değerlendirme durumu sorusuna satış ifadesine yönelik herhangi bir işaretleme yapılmamıştır. Mutki ilçesinde gübrenin daha çok bitkisel üretim amaçlı olarak değerlendirildiği anlaşılmaktadır. Bu durum bakımından ilçeler arasındaki farklılıklar istatistiksel olarak önemli bulunmuştur $(\mathrm{P}<0,01)$. Han ve Bakır (2010) Diyarbakır'da yaptıkları bir araştırmada gübreyi yakacak olarak kullanma oranın $1 \% 52,1$ olarak bildirmişlerdir. Ülkemizde gübrenin yeterince değerlendirilmediği açık bir konu olarak görülmekte, gübre yönetimi konusunda bir faaliyete yer verilmemektedir (Gültekin, 2014). Soyer (2014) Aydın yöresinde sığırcılık işletmelerinde gübre yönetimi konusunda yaptı̆̆ çalışmada, gübreyi doğrudan tarımsal amaçlı kullanım dışında değerlendiren hiçbir işletmeye rastlanmadığını bildirmektedir. Erkan (2005) Mersin yöresi büyükbaş hayvancılık işletmelerinde yaptığ 1 çalışmada, 57 hayvancılık işletmesinin büyük çoğunluğunda $(\% 84,21)$ gübrenin açıkta yığınlar biçiminde biriktirildiğini gözlemiştir.

\section{Hayvan Varlı̆ğ ve Yetiştirme ile İlgili Bilgiler}

Ankete katılan yetiştiricilerin işletme başına toplam manda varlığı ve sağmal manda sayısına ilişkin ortalamalar sırasıyla $8,84 \pm 0,75$ ve $3,92 \pm 0,26$ baş olarak bulunmuştur. İşletme başına manda sayısına ilişkin bu artışın önemli bir gelişme olarak kaydedilmesi gerekmektedir. Her ne kadar küçük işletme tipi hüviyetinde olsa bile, işletme büyüklügünde artış sağlamaya dönük bir eğilimin oluşmaya başladığı düşünülmektedir. Genç hayvanlar için değerlendirildiğinde ise çoğunlukla dişilerin elde tutulduğunu, buna karşılık bir yaşını tamamlayan erkek hayvanların elden çıkarıldığı anlaşılmaktadır. Mevcut araştırmada bazı işletmelerde besi ilkelerine dikkat edilmese de manda besisi yapıldığı gözlenmiştir. Yaşlı ve sakat hayvanlar ise canlı olarak kasaplara satılmaktadır. Araştırmada, kızgınlık takibini düzenli olarak yapan ve yapmayan yetiştiricilerin oranları sırasıyla $\% 75,00$ ve $\% 25,00$ 'dır. Aynı şekilde gebelik tayini yapan ve yapmayan yetiştiricilerin oranları sirasıla \%59,56 ve \%40,44'dir. Yapılan anket çalışmasında yetiştiriciler genellikle gebelik tayinini kızgınlık takibi yoluyla gerçekleştirdiklerini ifade etseler de genellikle bir kayıt tutma alışkanlığına sahip olmadıkları, aşımların köyün ortak sürüsü içinde rastgele gerçekleştirildiği anlaşılmıştır. İşletmelerde boğa bulunduran ve bulundurmayanların oranları sırasıly \%9,63 ve \%90,37'dir. Mutki ilçesinde manda yetiştiricilerinin hepsi boğa bulunduruyorum durumunu işaretlerken, Güroymak ilçesinde yetiştiricilerin yalnızca \%12,26'sı boğa bulundurduklarını ifade etmişlerdir. Dolayısılla boğa 
bulundurma durumu bakımından ilçeler arasındaki farkl11ıklar istatistiksel olarak önemli görülmüştür $(\mathrm{P}<0,01)$. Boğa bulundurmama durumu Bitlis ili mandacıllğı için önemli bir problem olarak değerlendirilmiştir. Mandalarda görülen bu durum büyük ekonomik kayıplara yol açmaktadır.

Çizelge 2. İşletmelerde bazı üreme özelliklerine ilişkin frekanslar (\%)

\begin{tabular}{|c|c|c|c|c|c|c|c|c|}
\hline \multicolumn{3}{|c|}{ Eşeysel olgunluk yaş1 (\%) } & \multicolumn{3}{|c|}{ İlkine doğurma yaşı (\%) } & \multicolumn{3}{|c|}{ Malaklama aralığ1 (\%) } \\
\hline $18-22$ (ay) & $23-24$ (ay) & $\geq 25$ (ay) & 24-36 (ay) & 37-43(ay) & $\begin{array}{c}44- \\
5 \text { (ay) }\end{array}$ & $\begin{array}{c}11-15 \\
\text { (ay) }\end{array}$ & 16-20 (ay) & $\geq 21$ (ay) \\
\hline 27.21 & 30,15 & 42,65 & 30,15 & 50,74 & 19,12 & 77,21 & 15,44 & 7,35 \\
\hline \multicolumn{3}{|c|}{ Damızlıkta kullanma süresi (\%) } & \multicolumn{3}{|c|}{ Damızlık temin durumu (\%) } & \multicolumn{3}{|c|}{ Boğa katım yöntemi } \\
\hline 6-10 (ay) & 11-15 (ay) & 16-20 (ay) & A & $\mathrm{B}$ & $\mathrm{C}$ & $\mathrm{A} 1$ & $\mathrm{~B} 1$ & $\mathrm{C} 1$ \\
\hline 33,82 & 52,21 & 13,97 & 15,44 & 40,44 & 44,12 & 14,71 & 85,29 & 0,0 \\
\hline
\end{tabular}

A: Kendi işletmesi, B: Komşu işletme, C: Her ikisi, A1: Kendi sürüsü içinde, B: Merada sürü içinde C1: İşletmede

Ülkemizde mandalarda yapay tohumlamaya ilişkin çalışmalar yeni başlatılmış olup bunun için biraz zamana ihtiyaç duyulmaktadır. Bu süreçte gözlemlenen yüksek kısırlıklar, temelde köyün ortak sürüsü içinde yeterli boğa bulundurmamaktan kaynaklanan nedenlerle, kızgınlıkların kaçırılmasından ileri gelmektedir. $\mathrm{Bu}$ nedenle mandaların üremesine ilişkin araştırmaların yaygınlaştırılarak devam ettirilmesi yerinde olacaktır (Küçükkebabçı ve Aslan, 2002; Atasever ve Erdem, 2008).

Çizelge 2'de ankete katılan yetiştiricilerin dişi mandalarda eşeysel olgunluk yaşı, ilkine doğurma yaşı, malaklama aralığı ve damızlıkta kullanma süresine ilişkin değerler verilmiştir. Buna göre 18-22, 23-24 ve 25 ay ve üstü yaşlardaki eşeysel olgunluk yaşı oranları sırasılyla \%27,21, \%30,15 ve $\% 42,65$ 'dir. Eşeysel olgunluk yaşı bakımından ilçeler arasındaki farklılıklar önemli bulunmuştur $(\mathrm{P}<0,05)$. Küçükkebabçı ve Aslan (2002) Anadolu mandasının sığırlardan düşük bir üreme performansına sahip olduğunu bildirmektedirler. Yılmaz (2013) Afyon yöresi mandalarda eşeysel olgunluk yaşının oldukça geç yaşlarda olduğunu bildirmiştir. Uslu (1970) Afyon Kocatepe Tarımsal Araştırma Enstitüsünde yetiştirilen Anadolu mandası düvelerinde ilk kızgınlığın 13-15. aylarda görüldügünü, 20-24. aylarda ise ilk defa boğaya verildiklerini bildirmiştir. İlkine doğurma yaş1 mandaların ilk malakladığı yaştır. Bu özellik sığır yetiştiriciliği için önemli bir ölçüt olup ortalama 24 aydır. Mevcut araştırmada 24-36, 37-43 ve 44-51 ay gruplarında ilkine doğurma yaşına ilişkin değerler sirasılyla \%30,15, \%50,74 ve \%19,12'dir. Eşeysel olgunluk yaşında olduğu gibi mandalarda ilkine doğurma yaşı da ekonomik manda yetiştiriciliği için tatmin edici olmaktan uzak görünmektedir. Yapılan araştırmalarda da benzer bulgular ortaya konulmuştur (Küçükkebabçı ve Aslan, 2002; Yılmaz, 2013). Bununla birlikte söz konusu özellikler bakımından gözlemlenen durumun sürü idaresi ve besleme faktörlerinin dışında tutulmaması gerektiği düşünülmektedir. Birbirini izleyen iki doğum arası süre olarak tanımlanan malaklama aralı̆̆ sürü idaresinde, üzerinde durulması gereken önemli bir ölçüttür. Sığır yetiştiriciliğinde ideal buzağılama aralığı 12 ay olup bu değer bazen 13 ay olabilmektedir (Kaya ve ark., 1998). Mevcut araştırmada 11-15, 16-20 ve 21 ay ve üstü malaklama aralığına ilişkin değerler sırasıyla \%77,21, \%15,44 ve \%7,35'dir.Tekerli ve ark.(2001) 1984-1998 yıllara ait verilerden yola çıkarak malaklama aralığını 442 gün olarak bildirmiştir. Caddy ve ark. (1983) iki farklı Nili-Ravi sürüsünde malaklama aralığını sırasıyla 497 ve 525 gün; Khan ve Akhtar (1999) ise aynı ırkta bu değeri 467 gün olarak saptamıştır. Chhikara ve ark. (1995) ise Murrah mandalarında bu değerin 472 gün olduğunu bildirmektedirler.

Bitlis ilinde mandaların damılıkta kullanma süresi değerlendirildiğinde 6-10, 11-15 ve 16-20 yıl damılılkta kullanma süresine ilişkin değerler sirasıly $\% 33,82, \% 52,21$ ve $\% 13,97$ 'dir. Mutki ilçesinde, mandaların daha uzun süre damızlıkta kullanıldıkları gözlenmiştir $(\mathrm{P}<0,01)$. Yılmaz (2013)mandaların damızlıkta kullanma süresi için yetiştiricilerin \%64'ünün 16-20 yaş, \%21'inin 20 yaşve üstü, \%11'inin 11-15 ay, \%4'ünün ise 6-10 yaş olarak ifade ettiklerini bildirmiştir. Mevcut araştırmada Bitlis ili manda yetiştiricilerinin mandalarını uzun süre sürüde tutma alışkanlığına sahip oldukları anlaşılmaktadır. Uslu (1970) köy koşullarında dişi mandaların 18-20 yaşa kadar sürüde tutulduğunu bildirmiştir. Bitlis ilinde bu yöndeki eğilimlerin halen devam ettirildiği ve mandaların uzun yıllar sürüde tutulduğu bu makalenin yazarları tarafından gözlenmiştir. Ancak, son yıllarda yetiştirici koşullarında yürütülen destekleme projeleri sürülerde gençleştirme yönünde bir eğilimin oluşmasına yol açmıştır. Özellikle yaşlı mandalarda sazlık ve çamurluk alanlardan kaynaklı olarak 
kalça anomalilerine sıklıkla rastlanmakta ve bu anomalilere bağlı olarak yaşlı hayvanlar sürüden ayıklanabilmektedir.

Damızlık temini durumuyla ilgili olarak kendi işletmesinde, komşu işletmelerde ve her ikisi ifadesine ilişkin değerler sırasıly $\% 15,44, \% 40,44$ ve $\% 44,12$ 'dir. Y1lmaz (2013) tarafından yapılan araştırmada damızlık temini konusundan komşu işletmelerden yararlanma yönünde bir alışkanlığın varlığına dikkat çekilmiştir. Özellikle Güroymak ilçesinde erkek bulundurma alışkanlığına pek dikkat edilmediği gözlenmiş olup çoğunlukla köyün boğasının kullanıldığı tespit edilmiştir. Ankete katılan yetiştiricilerin boğa katım yöntemi durumu değerlendirildiğinde ise merada-kendi sürüsü içinde ve merada karışık boğa katım yöntemine ilişkin oranlar sırasıyla \%14,71 ve \%85,29 bulunmuştur (Çizelge 2). Yılmaz (2013) yetiştiricilerin \%83'ünün kızgınlık gösteren dişi mandalarını köydeki başka bir yetiştiriciye ait bir boğaya aştırdığını, \%30'ünün kendi boğası ile aştırdığını, \%3'ünün yapay tohumlama yaptırdığını bildirmektedir. Yetiştiricilerin yardımsız ve yardımlı (Yetişstirici + Veteriner Hekim) doğum şekli ifadelerine ilişkin yanıtları sırasıyla \%33,09 ve \%66,91'dir. Katılımcıların büyük çoğunluğu mandalarda doğumun yardımlı gerçekleştiğini bildirmiştir. Büyükbaş hayvan yetiştiriciliğinde 1rka göre değişmekle birlikte doğum güçlüğü önemli bir problemdir. Örneğin Siyah Alaca sığırlarda buzağı doğum ağırlığı, doğum tipi ve buzağılama mevsimi gibi faktörler güç doğumun oluşmasında önemli değişkenler olduğu bildirilmektedir (Bayram ve ark., 2015).

Bitlis ili Anadolu mandalarında yetiştirme pratiklerine ilişkin frekanslar Çizelge3'de verilmiştir. İzgi ve ark. (1989)F1 melezi (Akdeniz İtalya x Anadolu mandası) mandalarda doğum ağırlığını erkeklerde 32,3 kg, dişilerde ise 32,0 kg olarak belirtmektedir. Yılmaz ve ark. (2017) Bitlis ili Anadolu mandalarında doğum ağırlığı, altınc1 ay canlı ağırlığı ve bir yaş ağırlığını sırasıyla 29,28, 97,51 ve $142,16 \mathrm{~kg}$ olarak bildirmişlerdir. Kul ve ark.(2018) Amasya yöresi Anadolu mandas1 malaklarında ortalama doğum ağırlığını erkek ve dişiler için sırasıyla $32,2 \pm 0,57$ ve $26,0 \pm 0,50 \mathrm{~kg}$ olarak saptamışlardır. Malaklarda doğum ağırlığı için bildirilen bu değerler mevcut araştırmadaki yetiştirici bildirimleriyle uyumlu görünmektedir. Katılımcıların \%50'si 0-10 arasında bir ölüm oranı bildirmekle birlikte kişisel gözlemlerimiz bazı köylerde çok daha yüksek ölüm oranlarını göstermektedir. Araştırmanın gerçekleştirildiği Bitlis ili Güroymak ve Mutki ilçelerinde malak ölümleri önemli bir sorun olarak ortaya çıkmaktadır. Ülkemizde hayvan hastalıkları konusunda manda özelinde akademik düzeyde çalışmalar sınırlı düzeydedir. Temelde bölgede sığırlar için uygulanan sağlık koruma programı doğrudan mandalara uygulanmaktadır. Bununla birlikte Afyon yöresi mandalarında yapılan çalışmada malaklarda yaşama gücü \%90-100 olarak bildirilmektedir (Yılmaz, 2013). Yetiştiricilerin doğumdan sonra malaklara bakılma durumuna ilişkin yanıtları değerlendirildiğinde analarlyla birlikte, özel bölmelerde ve diğer malaklarla birlikte ifadelerine ilişkin değerler \%54,41, \%17,65 ve \% 27,94'dür. Araştırmanın yürütüldüğü bölgede malaklar için özel bölmelere çok az yer verilmekte, çoğunlukla malaklar analarıyla birlikte veya diğer malaklarla birlikte bakılmaktadır. Bölmeler için ayrıca bir gider düşünülmemekte ve kendi imkânlarıyla ahşaptan bölmeler yapılmaktadır.

Çizelge 3. Bitlis ili Anadolu mandalarında malak doğum ağırlı̆̆ı, malak ölüm oranı ile bazı yetiştirme özelliklerine ilişkin frekanslar (\%)

\begin{tabular}{cccccc}
\hline $\begin{array}{c}\text { Malak doğum } \\
\text { ağırlı̆̆ } 1(\mathrm{~kg})\end{array}$ & $\begin{array}{c}\text { Frekans } \\
(\%)\end{array}$ & Malak ölüm oranı (\%) & $\begin{array}{c}\text { Frekans } \\
(\%)\end{array}$ & Malak bakım durumu & $\begin{array}{c}\text { Frekans } \\
(\%)\end{array}$ \\
\hline $10-20$ & 5,88 & $0-10$ & 52,21 & Analarıyla birlikte & 54,41 \\
$21-25$ & 11,76 & $11-30$ & 10,29 & Özel bölmelerde & 17,65 \\
$26-30$ & 27,21 & Daha yüksek & 37,50 & Diğer malaklarla birlikte & 27,94 \\
$31-35$ & 44,12 & & & & \\
$36-40$ & 11,03 & & & & \\
\hline Ağız sütü verme & Frekans & Ağız sütü verme şekli & $\begin{array}{c}\text { Frekans } \\
(\%)\end{array}$ & Ağız sütü verme süresi & Frekans \\
durumu & $(\%)$ & & (gün) & $(\%)$ \\
\hline Evet & 100 & Anadan direk emiyor & 90,44 & $1-2$ & 6,61 \\
Hayır & 0,00 & Biberonla içiriyorum & 9,56 & 3 & 63,24 \\
& & & & $>3$ & 30,15 \\
\hline
\end{tabular}

Yılmaz (2013) malak bakımına ilișkin analarıyla birlikte, özel bölmelerde ve diğer malaklarla birlikte ifadelerine yanıtları sırasıyla $\% 40, \% 30$ ve $\% 30$ olarak bildirmiştir. Araştırmada katılımcıların tamamı malaklarına ağız sütü vermektedir. Manda yetiştiricilerinin temelde ağız sütü konusunda bir 
bilgiye sahip oldukları görülmekle birlikte ăgız sütünün verilme şekli konusunda bir planları olmadığı gözlenmiş̧tir. Yılmaz (2013)manda yetiştiricilerinin \%90'dan fazlasının direk anadan emmek suretiyle ağız sütü verdiklerini bildirmiştir. Kolostrum, mandanın erken dönemlerindeki gelişim durumuna uygun maddeleri dengeli ve yeterli oranlarda içermektedir(Güngör, 2006). Ağız sütünün verilme şekline ilişkin olarak anadan emiyor ve biberonla içiriyorum ifadelerine ilişkin değerler sırasıyla $\% 90,44$ ve \%9,56'dir. Bu bulgu Yılmaz (2013) tarafindan elde edilen bulgularla uyumludur. Ankete katılan yetiştiricilerin ağız sütünün verilme süresine ilişkin yanıtları değerlendirildiğinde $1-2,3,3+$ gün ağız sütü vermesi durumu ifadesine ilişkin değerler sırasıyla \%6,61, \%63,24 ve \%30,15'dir. Dolayısıyla doğal ve gelişigüzel yöntemlerle de olsa manda yetiştiricileri doğumdan hemen sonra gelen ve normal sütten farklı olan bu sütün malaklar tarafindan alınmasını sağlamaktadır. Kolostrumun doğum sonras1 7-12. günde normal süt yapısına döndüğü düşünüldüğünde mevcut araştırmada ağız sütünün verilme süresi için 3 günden fazla durumuna katılan yetiştiricilerin olması önemlidir (Kume ve Tabana, 1993). Öte yandan bu sütün yetiştiriciler tarafından da tüketildiği gözlenmiştir. Ayrıca, ankete katılan yetiştiricilerin tamamı, malakların sütten kesim zamanı ifadesine sütten kesmiyorum şeklinde ifade ettikleri görülmüş̧ür. Bu bulgunun Bitlis ili manda yetiştiriciliği konusunda önemli bir bulgu olduğu düşünülmektedir. Ayrıca sağımın ancak malak varlığında gerçekleştirilebildiğine ilişkin yetiştirici bildirimleri de önemli bulunmuştur. Malağ 1 yanında bulundurulmayan mandanın sağıma izin vermediği gözlenmiştir. Ancak bu durumun yol açtığı ekonomik kayıplar düşünüldüğünde mandalarda bu yönde bir davranış değişikliğinin sağlanması konusunda bazı uygulamalara ihtiyaç duyulduğunu göstermektedir. Özellikle malak besisine ilişkin olarak oluşacak olası bir bilinç yetiştiricileri bu yönde yeni arayışları ve yenilikleri benimsemesine yardımcı olacağı açıktır(Aksoy ve Alpan, 1991).

\section{Sağımla İlgili Bilgiler}

Ankete katılan yetiştiricilerin tamamı, sağım işleminin nerede ve nasıl yapıldı̆̆ 1 ifadesine ahırda-elle sağım şeklinde ifade ettikleri görülmüş̧ür. Yılmaz (2013) araştırmasında yetiştiricilerin \%84'ünün sağımın ahırda elle, \%10'unun ahırda makine ile \%6'sının ise ahır dışında elle yapıldığını bildirmiştir. Yazar bu yetiştirme alışkanlığının değiştirilmesi oldukça zor görünmekle birlikte makineli sağıma geçişle birlikte bunun kendiliğinden gerçekleşebileceği belirtilmiştir. Dolayısıyla mevcut araştırmadaki işletmelerin hiçbirinin bir sağım ünitesine ve yerine sahip olmadığı anlaşılmaktadır. Makine ile sağım bir yana ahırda elle sağımda asgari hijyen koşullarına bile dikkat edilmediği gözlenmiştir. Katılımcıların büyük çoğunluğu sağım öncesi memeye masaj yaptıklarını $(\% 88,97)$ ifade etmişlerdir. Sağım sırasında mandalara yem veren ve vermeyen yetiştiricilerin oranları sırasıyla $\% 46,32$ ve $\% 53,68$ 'dir. Sağım uygulamalarında meme temizliği ve masaj işlemi sütün indirilmesinde oldukça önemlidir. Yapılan araştırmada bu kritik işlemi yapmakla birlikte sağım sırasında mandalara yem verilmesi konusunda önemli bir eğilim taşımadıkları görülmüştür. Bunun mandalarda sağımın malaklarla birlikte yapılması alışkanlığından ileri geldiği düşünülmektedir.

Mandaların süt verimine ilişkin yetiştiricilerin bildirimlerine göre günlük süt verimi ortalaması

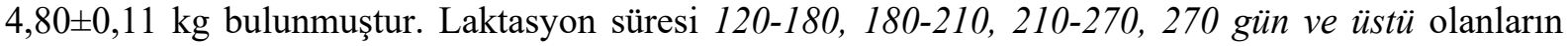
oranları ise sirasıyla $\% 11,76, \% 30,15, \% 48,53$ ve $\% 9,56$ 'dır. Buna göre Güroymak ilçesinde $120-180$ gün, 180-210 gün, 210-270 gün ve 270'den fazla laktasyon süresi durumu için frekans değerleri sırasıly $\% 14,95, \% 23,36, \% 50,47$ ve $\% 11,21$ 'dir. Mutki ilçesinde ise aynı laktasyon süresi durumu aralıkları için değerler $\% 0, \% 55,17, \% 41,38$ ve $\% 3,48$ olarak bulunmuştur $(\mathrm{P}<0,01)$. Anadolu mandasında laktasyon süt verimi irk, yaş, laktasyon sırası ve bakım besleme koşullarına göre değişmekle birlikte ortalama $925 \mathrm{~kg}$ olduğu bildirilmektedir. Yapılan bir çalışmada Anadolu mandasında laktasyon süt verimi 350-1580 kg değiştiği ortalama olarak 943,2 kg olduğu saptanmıştır. Afyon Kocatepe Tarımsal Araştırma Enstitüsünde uzun yıllar devam ettirilen ıslah çalışmalarında (Uslu, 1970; İzgi ve ark., 1989) laktasyon süt veriminin600-800 kg arasında değiştiği bildirilmektedir. Bununla birlikte Şekerden (2000) ile Y1lmaz ve ark. (2017) Anadolu mandalarında laktasyon süt verimini sırasıyla 1070 ve $963 \mathrm{~kg}$ olarak saptamışlardır. Başka genotiplerde yapılan çalışmalarda İtalya ve Yunanistan mandalarında 305 günlük süt verimi sırasıyla, 2000 ve 700-1000 kg bildirilmiştir (Elisei ve Chichernea, 1991; Stravaridou, 1998). Nili-Ravi ve Murrah mandalarında ise bu değerler 1841 ile $1954 \mathrm{~kg}$ arasında tespit edilmiştir (Caddy ve ark., 1983; Dhara ve Chakravarty, 1996). Dolayısıyla ülkemizde Anadolu mandasına ilişkin elde edilen bulgular mevcut araştırmadaki yetiştirici 
bildirimleriyle uyumlu olduğu düşünülmektedir. Şahin ve Ulutaş (2014) farklı laktasyon süt verimi yöntemlerine dayanarak Anadolu mandasında laktasyon süt verimini 654,7-761 kg aralığında değiştiğini bildirmektedirler. Tekerli ve ark. (2001) çeşitli yıllarda tutulan verilere dayanarak Anadolu mandasında kuruda kalma süresi ve laktasyon süresini sirasılyla 231,16 ve 221 gün olarak bildirmişlerdir. Yılmaz ve ark. (2017) Bitlis ili Anadolu mandalarında laktasyon süresini 262,63 gün; Şahin ve Ulutaş (2014) yukarda belirtilen aynı çalışmalarında Anadolu mandasında laktasyon süresini

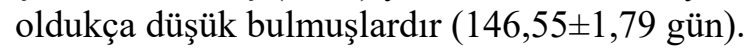

Ankete katılan yetiştiricilerin günde sağım sayıları 1-2, 2 sağım laktasyonun son iki ayı bir să̆ım yapan yetiştiricilerin oranları sırasıyla \%72,79 ve \%27,21'dir. Dolayısıyla Bitlis ili manda yetiştiriciliğinde temelde iki sağım yapıldığı anlaşılmaktadır. Genelde verim yönü dikkate alınacak şekilde bir yetiştiricilik sistemi gelişmediğinden yetiştirici açısından bir ekonomik değerlendirme söz konusu olmamaktadır. Yılmaz (2013) yetiştiricilerin \%43'ünün günde 2 sağım, \%57'sinin ise günde iki sağım fakat kuruya çıkmasına 2 ay kala günde 1 defa sağım yaptıklarını bildirmektedir. Araştırmada günde tek sağım beyan eden yetiştirici bulunmamıştır. Uslu (1970) köylü koşullarında çoğunlukla iki sağım yapıldığını, laktasyonun ortasında ise bunun tek sağıma düştüğünü bildirmektedir. Elde edilen sütün muhafaza yöntemine ilişkin yetiştiricilerin yantları değerlendirildiğinde ise, süt kaplarında-dışarıda, süt kaplarında-buzdolabında ve süt kaplarında hem dışarıda hem de buzdolabında muhafaza edenlerin oranları sırasıyla $\% 28,68, \% 38,97$ ve $\% 32,35$ 'dir. Bununla birlikte soğutma tankında ifadesine yönelik herhangi bir işaretleme yapılmamıştır. Yılmaz (2013) yetiştiricilerin tamamının süt sağılır sağılmaz pişirdiklerini ve kaymak yapmak için özel kaplara aldıklarını bildirmiştir. Özellikle Afyon kaymağına yönelik üretim söz konusu olduğundan bu durum yetiştiricilere üretim noktasında bir hedef sunmaktadır. Ancak mevcut araştırmada Bitlis ili bağlamında sütün değerlendirilmesi konusunda böyle bir açıklık bulunmamaktadır. Yetiştiriciler manda sütünü çoğunlukla yoğurt, peynir ve kaymak yaparak değerlendirdikleri gözlenmiştir.

\section{Sonuç ve Öneriler}

Bitlis ili Anadolu mandası işletmelerinin genel yapısal özellikleri aşağıda özetlenmiş ve muhtemel çözüm önerileri ortaya konulmuştur:

1- Bitlis ilinde manda yetiştiriciliği, önemli bir istihdam alanı olmakla birlikte, küçük aile tipi hüviyetinde, eğitim düzeyi okuryazar değil ve ilkögretim eğitim durumuna sahip, orta yaş grubu veya daha büyük yaş grubundaki yetiştiriciler tarafindan gerçekleştirilmektedir. Araştırmada yetiştiricilerin çoğunlukla erkeklerden oluştuğu görülmekle birlikte işgücü anlamında kadınların ağır sorumluluklar üstlendikleri tahmin edilmektedir. Bu yönde yapılacak projelerde kadınların üretimdeki bu önemli rollerinin dikkate alınması ve kayıt altına alınmasını kaçınılmaz kılmaktadır.

2- Bitlis ilinde barınak giderleri ve işçi giderleri anlamında bir maliyet söz konusu değildir. Şahsa ait kapalı barınak tiplerinin tercih edildiği yörede barınak koşulları hem insan hem de hayvan sağlığı açısından büyü riskler taşımaktadır. Özellikle sert iklim koşulları gerekçe gösterilerek yeterli pencere kullanımına ve havalandırma bacasına yer verilmemekte, var olan pencereler ise kış aylarında kapatılmaktadır.

3-Bitlis ili manda yetiştiricilerinin başta kızgınlık takibi olmak üzere mandalarda üremeye ilişkin konularda bir takım faaliyetleri yerine getirdiklerini ifade etmekle birlikte, bölgede gözlemlenen yüksek kısırlık oranları bunun çok etkili olmadığını göstermektedir. Konuyla ilgili olarak birlik üzerinden yönlendirmeler yapılabilir ve bazı eğitim programlarına yer verilebilir. Ayrıca ülkemizde manda yetiştiriciliği konusunda akademik düzeyde çalışmalara yer verilmesi, üniversitelerimizin Ziraat ve Veteriner fakültelerinde ders müfredatlarında konuyla ilgili derslerin konulması önerilebilir.

4- Mandalarda hem laktasyon süt verimi hem de büyüme gelişme özelliklerine ilişkin ortalamalar ekonomik bir manda yetiştiriciliği için yeterli görünmemektedir. Ülkemizde hali hazırda yürütülen projelerle Anadolu mandasının halk elinde seleksiyonla ıslahı çalışmalarından önemli bir ilerleme hedeflenmektedir.

5- Ankete katılan yetiştiricilerin tamamı, malakların sütten kesim zamanı ifadesini "sütten kesmiyorum" şeklinde ifade ettikleri görülmektedir. Ayrıca sağımın ancak malak varlığından gerçekleştirilebildiğine ilişkin yetiştirici bildirimleri de önemli bulunmuştur. Ancak bu durumun yol 
açtığ1 ekonomik kayıplar düşünüldüğünde, mandalarda bu yönde bir davranış değişikliğinin sağlanması konusunda bazı uygulamalara ihtiyaç duyulduğunu göstermektedir.

Not: Bu makale birinci yazarın "Bitlis İli Anadolu Mandası İşletmelerinin Yapısal Özellikleri Üzerine Bir Araştırma" adlı yüksek lisans çalışmasına dayanılarak hazırlanmıştır.

\section{Teșekkür}

Bu araştırma Siirt Üniversitesi Bilimsel Araştırmalar Projeleri Başkanlığı tarafından 2016-Sİ̈̈FEB31 numaralı proje olarak desteklenmiştir.

\section{Kaynaklar}

Aksoy, A.R., Alpan, O., 1991.Rasyonlardaki farklı protein düzeylerinin mandalarda besi performansı, kesim ve karkas özellikleri üzerine etkisi. Turkish Journal of Veterinary and Animal Sciences. 15:164-176.

Anonim, 2004. Yerli Hayvan Irk ve Hatlarının Tescili Hakkında Tebliğ (2004/39). 12 Aralık 2004 Tarih ve 25668 Sayılı Resmi Gazete. Ankara.

Anonim, 2007. Dünya ve Türkiye'de Mandacilık. http://web.ttnet.net.tr/kocatepe/Dunyada veTurkiyede mandacilik.htm. Erişim tarihi 2 Mart 2018.

Atasever, S., Erdem, H., 2008. Manda yetiştiriciliği ve Türkiye'deki geleceği. Ondokuz Mayıs Üniversitesi, Ziraat Fakültesi Dergisi. 23(1):59-64.

Bayram, B., Topal, M., Aksakal, V., Önk, K., 2015. Genetiksel olmayan faktörlerin Siyah Alaca sığırlarda güç ve ölü doğuma etkilerinin CHAID analizi ile incelenmesi. Kafkas Üniversitesi Veteriner Fakültesi Dergisi. 21 (5):645-652.

Budağ, C., Keçeci, Ș., 2013. Van'da büyükbaş hayvan besilerinde kullanılan yemler ve besi şekillerine ilişkin bir anket çalışması. Yüzüncü Yıl Üniversitesi, Fen Bilimleri Enstitüsü Dergisi. 18(1-2):48-61.

Caddy, R.A., Shah, S.K., Schermerhorn, E.C., Mcdowell, R.E., 1983. Factors affecting performance of Nili-Ravi buffaloes in Pakistan. Journal Dairy Science. 66:578-586.

Chhikara, S.K., Singh, N., Dhaka, S.S.,Yadav, R.S., 1995. Effect of certain factors on calving interval of Murrah Buffaloes. DairyFoods Home Sci.14(1):29-32.

Çayır, M., Atılgan, A., Öz, H., 2012. Büyükbaş hayvan barınaklarındaki gübrelikler ve su kaynaklarına olan durumlarının incelenmesi. Süleyman Demirel Üniversitesi Ziraat Fakültesi Dergisi. 7(2):1-9.

Dhara, S.K., Chakravarty, A.K., 1996. Effect of genetic and non-genetic factors on production traits of Murrah Buffaloes. Dairy Foods Home Science. 15(1):119-124.

Elisei, L., Chichernea, P., 1991. Buffalo breeding in Brasov district. Third World Buffalo Congress, 2: 491-49, 13-18 May, Varna, Bulgaria.

Erkan, M., 2005. Mersin Yöresindeki büyükbaş hayvancıllk tesislerinin mevcut durumu ve bu tesislerde ortaya çıkan atıkların yarattı̆̆ı çevre kirliliği üzerinde bir araştırma. Çukurova Üniversitesi Fen Bilimleri Enstitüsü yayınlanmamış Yüksek Lisans Tezi. 96 s.

Göncü, S., Gökçe,G., 2017.Türkiye'de sığır besiciliği işletmelerinde karlı ve sürdürülebilir üretim için teknolojik uygulamalar. Çukurova Tarım Gıda Bilimleri Dergisi. 32:29-34.

Gültekin, C., 2014. Trakya Bölgesi'nde büyükbaş hayvancıllk işletmelerinin üretim-pazarlama sorunları ve çözüm önerileri. Trakya Üniversitesi. Sosyal Bilimler Enstitüsü, İşletme Anabilim Dalı, Yüksek Lisans Tezi. $119 \mathrm{~s}$.

Güneş, Ö., Arıkan, R., 1989. Tarım Ekonomisi İstatistiği. Ankara Üniversitesi Ziraat Fakültesi, Yayın No: 1049, Ders Kitabi: 305, Ankara

Güngör, Ö., 2006. Neonatal buzağılar ve kolostrum. Kafkas Üniversitesi veteriner Fakültesi Dergisi. 12(1):103108

Han, Y., Bakır, G., 2010. Özel besi işletmelerinin barınak yapısı ve etkileyen faktörler. Atatürk Üniversitesi Ziraat Fakültesi Dergisi. 41(1):45-51.

İzgi, A.N., Asker, R., Karabulut, A., Sabaz, S., Kazandağlı, M., 1989. Yerli ırk mandaların melezleme ile 1slah olanakları üzerinde bir araştırma. Mandacılık Araştırma Enstitüsü,Yayın No: 20, Afyon.

Kaya, A., Yaylak, E., Önenç, A., 1998. Süt sığırcılığında düzenli üreme ve önemi. Hayvansal Üretim Dergisi. 38:8-17.

Kayar, Y., 2011. Denizli yöresi süt sığırcıllğı işletmelerinde barınakların yapısal yönden değerlendirilmesi. Adnan Menderes Üniversitesi, Fen Bilimleri Enstitüsü, Tarımsal Yapılar ve Sulama Anabilim Dalı, Yüksek Lisans Tezi. $124 \mathrm{~s}$.

Khan, R.N., Akhtar, S., 1999. Production characteristics of Nili-Ravi buffaloes. Asian-Australas Journal Animal Science. 12:56-60.

Kul, E., Filik, G., Şahin, A., Çayıroğlu, H., Uğurlutepe, E., Erdem, H., 2018. Effects of some environmental factors on birth weight of Anatolian buffalo calves. Turkish Journal of Agriculture-Food Science and Technology. 6(4):444-446. 
Kume, S., Tanaba, S., 1993. Effect of parity on colostral mineral concentrations of Holstein and value of colostrom as a mineral souce for newborn calves. Journal Dairy Science. 76:1654-1660.

Küçükkebapçı, M., Aslan, S., 2002. Evcil dişi mandaların üreme özellikleri. Lalahan Hay. Araştırma Enstitüsü Dergisi. 42(2):55-63.

Özenç, E., Vural, M.R., Şeker, E., Uçar, M., 2008: An evaluation of subclinical mastitis during lactation in Anatolian buffaloes. Turkish Journal of Veterinary and Animal Sciences. 32(5):359-368.

Özdemir, G., Özdemir, A., 2016. Bingöl ili manda yetiştiriciliğinin sorun ve çözüm önerilerinin yetiştirici gözüyle değerlendirilmesi. Iğdır Ǘniversitesi Fen Bilimleri Enstitüsü Dergisi. 6(2):157-164.

Sarıözkan, S., 2011. Türkiye'de manda yetiştiriciliğinin önemi. Kafkas Üniversitesi Veteriner Fakültesi Dergisi. 17(1):163-166.

SAS, 2017. SAS/STAT Software:SASInstInc, USA.

Soyer, G., 2014.Aydın ili süt sığırcılığı işletmelerinde gübre yönetim uygulamaları ve bitkisel üretimde gübre kullanım olanaklarının geliştirilmesi. Adnan Menderes Üniversitesi, Fen Bilimleri Enstitüsü, Tarımsal Yapılar ve Sulama Anabilim Dalı, Yüksek Lisans Tez. $100 \mathrm{~s}$.

Soysal, M.İ., 2009. Manda ve ürünleri Üretimi. Tekirdağ Üniversitesi Ziraat Fakültesi Zootekni Bölümü, Ders Notları. ISBN NO: 978-9944-5405-3-7, 237s, Tekirdağ.

Soysal, M.İ., 2013. Anatolian Water Buffaloes Husbandry in Turkey. Buffalo Bulletin. 32(1):293-309.

Stravaridou, S., 1998. Buffalo Population and Production in Greece. FAO Buffalo Newsletter. 9: 7.

Şahin, A., Ulutaş, Z., 2014. Anadolu mandalarının değişik metotlara göre tahmin edilen süt verimleri üzerine bazı çevresel faktörlerin etkilerinin belirlenmesi. Kafkas Üniversitesi Veteriner Fakültesi Dergisi. 20(1):79-85.

Tekerli, M., Küçükkebabcı, M., Akalin, N.H., Koçak, S., 2001. Effects of environmental factors on some milk production traits, persistency and calving interval of Anatolian buffaloes. Livest Prod Sci. 68:275-28.

Tugay, A., Bakır, G., 2006. Giresun yöresindeki özel süt sığırcılığı işletmelerinin ırk tercihleri ve barınakların yapısal durumu. Atatürk Üniversitesi Ziraat Fakültesi Dergisi. 37(1):39-47.

Uslu, N.T., 1970. Afyon Bölgesi mandalarının çeşitli özellikleri ile rasyonel ve köy şartlarında süt verimleri üzerinde mukayeseli araştırmalar. Doktora Tezi. Birlik Matbaası, $83 \mathrm{~s}$.

Yılmaz, A., Ocak, E.,Köse, Ş., 2017. A research on milk yield, milk composition and body weights of Anatolian buffaloes. Indian Journal Animal research. 51(3):564-569.

Yılmaz, S., 2013. Afyonkarahisar Yöresi Manda Yetiştiriciliği: Küçükçobanlı Köyü Örneği, Adnan Menderes Üniversitesi, Fen Bilimleri Enstitüsü, Zootekni Anabilim Dalı, Yüksek Lisans Tezi, 170 s. 